\title{
Use of Evidence-Based Therapy at Discharge for Patients with Acute Myocardial Infarction: Retrospective Audit of Medical Records
}

\author{
Stephanie W Young, John J Hawboldt, and Neil J Pearce
}

\begin{abstract}
Background: Various guidelines are available outlining optimal therapy for patients with acute myocardial infarction. Canadian institutions providing care for such patients have been encouraged to evaluate their care processes using specific indicators.

Objective: To determine the proportion of patients with acute myocardial infarction discharged from a single health authority for whom acetylsalicylic acid (ASA), adrenergic ß-receptor antagonists (ß-blockers), angiotensin-converting enzyme (ACE) inhibitors, or 3-hydroxy-3-methylglutaryl coenzyme A (HMG-CoA) reductase inhibitors (statins) had been prescribed.

Methods: Patients treated over a 12-month period (April 1, 2004, to March 31, 2005) for whom the most responsible diagnosis was acute myocardial infarction were eligible for inclusion in this review. Retrieved data included diagnosis, demographic information, comorbidities, and medications at the time of admission and discharge. Rates of discharge prescribing for the 4 drug classes were calculated for all patients and for "ideal" patients (those without documented contraindications). Rates were compared with published benchmark values.

Results: Medical records for a total of 346 eligible patients were reviewed. Mean age was 65.3 years (standard deviation 13.4 years), and $226(65.3 \%)$ of the patients were male. The coded diagnosis was ST-elevation myocardial infarction for 91 patients $(26.3 \%)$, non-STelevation myocardial infarction for 164 (47.4\%), and myocardial infarction not specified for 91 (26.3\%). For "ideal" patients, the prescribing rates were $99.0 \%$ (308 of 311 patients) for ASA, 96.3\% (310 of 322 patients) for ß-blockers, 90.4\% (264 of 292 patients) for ACE inhibitors, and $88.8 \%$ (278 of 313 patients) for statins.

Conclusions: Rates of prescribing of ASA, B-blockers, ACE inhibitors, and statins for "ideal" patients discharged after treatment for acute myocardial infarction exceeded the published Canadian benchmark rates ( $\geq 90 \%$ for ASA, $\geq 85 \%$ for $ß$-blockers and ACE inhibitors, $\geq 70 \%$ for statins).
\end{abstract}

Key words: myocardial infarction, drugs, quality of care

Can J Hosp Pharm 2010;63(3):207-211

\section{RÉSUMÉ}

Contexte : Il existe diverses lignes directrices décrivant le traitement optimal pour les patients ayant subi un infarctus aigu du myocarde. Les établissements de santé canadiens qui soignent de tels patients ont été encouragés à évaluer leurs processus de soins en utilisant des indicateurs précis.

Objectif : Déterminer la proportion de patients ayant subi un infarctus aigu du myocarde et ayant reçu leur congé d'une seule régie de la santé avec une prescription d'acide acétylsalicylique (AAS), d'antagoniste des récepteurs $\beta$-adrénergiques ( $\beta$-bloquant), d'inhibiteur de l'enzyme de conversion de l'angiotensine (ECA) ou d'inhibiteur de la 3-hydroxy3-méthylglutaryl-coenzyme A (HMG-CoA) réductase (statine).

Méthodes : Les patients traités sur une période de 12 mois (entre le $1^{\text {er }}$ avril 2004 et le 31 mars 2005) et dont le diagnostic le plus responsable était celui d'infarctus aigu du myocarde étaient admissibles à l'analyse. Les données recueillies incluaient le diagnostic, les renseignements démographiques, les comorbidités et les médicaments au moment de l'admission et du congé. Un taux de prescription au congé pour les quatre classes de médicaments a été calculé pour tous les patients et pour les patients "idéaux" (ceux sans contre-indications documentées). Ces taux ont été comparés aux références optimales publiées.

Résultats : Les dossiers médicaux d'un total de 346 patients admissibles ont été analysés. L'âge moyen des patients était de 65,3 ans (écart-type de 13,4 ans) et $226(65,3 \%)$ des patients étaient des hommes. Le diagnostic codé était un infarctus du myocarde avec élévation du segment ST (91 patients ou 26,3\%), un infarctus du myocarde sans élévation du segment ST (164 ou 47,4\%) et infarctus du myocarde non précisé (91 ou 26,3\%). Pour les patients "idéaux ", les taux de prescription étaient de 99,0\% (308 des 311 patients) pour l'AAS, de 96,3\% (310 des 322 patients) pour les $\beta$-bloquants, de 90,4\% (264 des 292 patients) pour les inhibiteurs de l'ECA et de 88,8\% (278 des 313 patients) pour les statines.

Conclusions : Les taux de prescription d'AAS, de $\beta$-bloquants, d'inhibiteurs de l'ECA et de statines pour les patients "idéaux " ayant reçu leur congé après le traitement de l'infarctus du myocarde dépassaient les taux de référence canadiens publiés ( $\geq 90 \%$ pour l'AAS, $\geq 85 \%$ pour les 3 -bloquants et les inhibiteurs de l'ECA, $\geq 70 \%$ pour les statines).

Mots clés : infarctus du myocarde, médicaments, qualité des soins

[Traduction par l'éditeur] 


\section{INTRODUCTION}

$\mathrm{O}$ ver the past 20 years, treatment of acute myocardial infarction has improved through more rapid recognition of symptoms, treatment with fibrin-specific thrombolytics and percutaneous coronary intervention, and clinical trials that have demonstrated reductions in morbidity and mortality with appropriate acute treatment and secondary prevention., ${ }^{1,2}$ Specifically, evidence now supports the use of acetylsalicylic acid (ASA), adrenergic B-receptor antagonists (B-blockers), angiotensin-converting enzyme inhibitors (ACE inhibitors), and 3-hydroxy-3-methylglutaryl coenzyme A (HMG-CoA) reductase inhibitors (statins) for eligible patients who have experienced acute myocardial infarction. ${ }^{1,2}$ This information has led to the publication of guidelines outlining optimal treatments for patients with acute myocardial infarction. ${ }^{1,2}$ From these guidelines, processes of care have been developed to ensure that patients receive evidence-based care that will improve outcomes.

Before 2003, published reports from the United States and Canada ${ }^{4,5}$ indicated that the use of these medications remained suboptimal. To improve the use of proven therapies and to ensure that care for patients with acute myocardial infarction reflected the standards of the Canadian health care system, the Canadian Cardiovascular Outcomes Research Team/Canadian Cardiovascular Society (CCORT/CCS) developed a set of quality indicators. ${ }^{6}$ The benchmark or minimum target levels set for the medications listed above, in terms of prescription rate at discharge for "ideal" patients (those without contraindications to the therapy), were at least $90 \%$ for ASA, at least $85 \%$ for $ß$-blockers, at least $85 \%$ for ACE inhibitors, and at least $70 \%$ for statins. ${ }^{6}$

Canadian institutions providing care to patients with acute myocardial infarction were encouraged to evaluate their care processes using these benchmarks. Other Canadian initiatives, such as Safer Healthcare Now!, have supported these goals. With the publication of these initiatives, there was interest in evaluating the level of care at the authors' institution. Eastern Health is the largest health authority in Newfoundland and Labrador, providing tertiary care to a population of over 290000 people and specialized cardiac services for the entire provincial population (more than 500000 individuals).

The objective of this study was to determine the proportion of patients discharged from 2 tertiary care sites of Eastern Health with a diagnosis of acute myocardial infarction who had a discharge prescription for ASA, ß-blocker, ACE inhibitor, or statin and to compare these results with the national benchmarks.

\section{METHODS}

This retrospective study involved patients discharged from 2 adult acute care sites of Eastern Health. At the time of the study, the 2 sites had a total of about 550 acute care beds, and each contained a coronary care unit. One of these sites housed the cardiac catheterization laboratory and the cardiac surgery program for the entire province. During the 2007/2008 fiscal year, a total of 526 coronary artery bypass graft procedures and 766 percutaneous coronary interventions were performed. Eastern Health is also affiliated with the province's only university (Memorial University of Newfoundland), having particularly strong links to its medical and allied health professional schools.

Patients were identified from Eastern Health's administrative database on the basis of the International Classification of Diseases, 9th Revision (ICD-9) code for acute myocardial infarction. Patients were eligible for inclusion in the review if they had been discharged with a primary (most responsible) diagnosis of acute myocardial infarction between April 1, 2004, and March 31, 2005.

One research nurse collected data from the patients' medical records using a standardized data collection form (Online Appendix 1 at www.cjhp-online.ca/index.php/cjhp/ issue/view/75). These data included descriptive information (i.e., demographic characteristics, type of myocardial infarction, relevant comorbidities, and medications on admission and discharge) and additional evidence of contraindications or criteria that would exclude a patient from therapy (e.g., serum creatinine concentration, left ventricular function). The data collected were limited to details documented in the medical record. For each patient, the medication classes of interest were deemed to have been prescribed on discharge if a discharge prescription had been written or if the drug was listed in the patient's discharge summary.

The CCORT/CCS document ${ }^{6}$ listed exclusions for each of the classes of medications (Table 1). For patients for whom the medications of interest had not been prescribed on discharge, information was sought to determine if at least one of the exclusion criteria applied.

Data analysis was performed using SPSS statistical software for Windows (version 15.0; SPSS Inc, Chicago, Illinois). Frequencies, means, and standard deviations (SDs) were used to describe the patients' characteristics. Rates of discharge prescribing for the 4 classes of medications were calculated for all patients, as well as for the subset of "ideal" patients for each drug class (i.e., those without documented contraindications or reasons for nonprescribing). The rates for "ideal" patients were compared with the CCORT/CCS benchmarks. This project was approved by the Human Investigations Committee, Memorial University of Newfoundland.

\section{RESULTS}

\section{Patient Characteristics}

Medical records for a total of 346 patients were reviewed. The mean age $( \pm S D)$ of patients was $65.3 \pm 13.4$ years, and 


\section{Table 1. Potential Exclusions for Medication Classes Noted by the Canadian Cardiovascular Outcomes Research Team/Canadian Cardiovascular Society*}

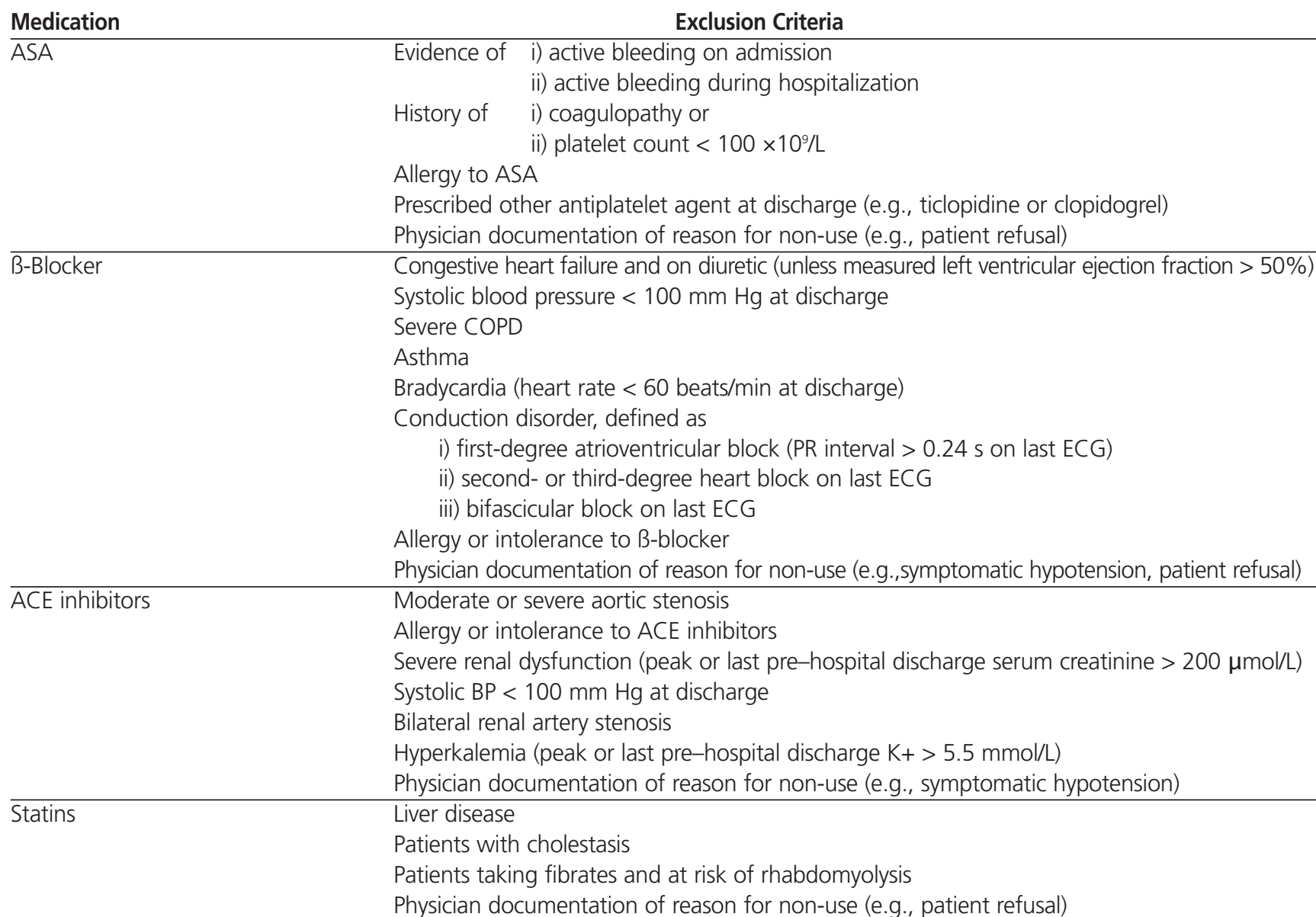

$\overline{\mathrm{ACE}}=$ angiotensin-converting enzyme, $\mathrm{ASA}=$ acetylsalicylic acid, $\mathrm{BP}=$ blood pressure, $\mathrm{COPD}=$ chronic obstructive pulmonary disease, ECG = electrocardiogram.

*Reproduced, with permission from the Pulsus Group, from Tran CT, Lee DS, Flintoft VF, Higginson L, Grant FC, Tu JV, et al. ${ }^{6}$ CCORT/CCS quality indicators for acute myocardial infarction care. Can J Cardiol 2003;19(1):38-45.

almost two-thirds (226 [65.3\%]) were male (Table 2). Before admission, approximately half of the patients had dyslipidemia (181 [52.3\%]) or hypertension (197 [56.9\%]), and almost one-third $(100[28.9 \%])$ had a history of acute myocardial infarction. Each medication of interest was prescribed to more than one-third of the patients at the time of admission. For the 100 patients with a history of acute myocardial infarction, the prescribing rates for the 4 medication classes at the time of admission were lower than the established benchmarks: $60.0 \%$ (60 patients) for ASA, 66.0\% (66 patients) for B-blockers, $57.0 \%$ (57 patients) for ACE inhibitors, and 50.0\% (50 patients) for statins.

\section{Prescribing Rates at Discharge for Medications of Interest}

The prescribing rates for the 4 medication classes were above established benchmarks (Table 3). Most of the "ideal" patients had a discharge prescription for ASA (308 [99.0\%] of 311 patients) and a B-blocker (310 [96.3\%] of 322). The rates of discharge prescribing were slightly lower for ACE inhibitors (264 [90.4\%] of 292) and statins (278 [88.8\%] of 313). For each medication, the number of patients for whom the drug had not been prescribed and for whom we could not locate documentation of at least one exclusion criteria or reason for nonprescribing at discharge were 3 for ASA, 12 for ß-blockers, 28 for ACE inhibitors, and 35 for statins.

\section{DISCUSSION}

In this study of patients treated in hospital for acute myocardial infarction, the prescribing rates at discharge for the 4 classes of medications were higher than established benchmark values. One-third to one-half of the patients were already receiving one or more of the medications of interest at admission. This finding is clinically significant, as improve- 
Table 2. Characteristics of 346 Patients in a Retrospective Analysis of Therapy at Discharge after Myocardial Infarction

\begin{tabular}{lrr} 
Characteristic & \multicolumn{2}{c}{$\begin{array}{c}\text { No. (\%) } \\
\text { of Patients* }\end{array}$} \\
\hline Age (years) (mean \pm SD) & $65.3 \pm$ & 13.4 \\
\hline Sex, males & 226 & $(65.3)$ \\
\hline Discharge diagnosis & 91 & $(26.3)$ \\
ST segment-elevation myocardial infarction & 164 & $(47.4)$ \\
Non-ST segment-elevation myocardial infarction & 91 & $(26.3)$ \\
Myocardial infarction not specified & & \\
\hline Medical history & 29 & $(8.4)$ \\
Cerebral vascular accident & 28 & $(8.1)$ \\
Chronic kidney disease & 42 & $(12.1)$ \\
Chronic obstructive pulmonary disease & 121 & $(35.0)$ \\
Current smoker & 99 & $(28.6)$ \\
Diabetes mellitus & 181 & $(52.3)$ \\
Dyslipidemia & 97 & $(28.0)$ \\
Gastrointestinal disorders & 100 & $(28.9)$ \\
History of myocardial infarction & 197 & $(56.9)$ \\
Hypertension & 26 & $(7.5)$ \\
Previous percutaneous coronary intervention & 31 & $(9.0)$ \\
Previous coronary artery bypass graft surgery & & \\
\hline Medications on admission & & \\
Medications of interest & 138 & $(39.9)$ \\
Acetylsalicylic acid & 137 & $(39.6)$ \\
B-Blocker & 142 & $(41.0)$ \\
Angiotensin-converting enzyme inhibitor & 120 & $(34.7)$ \\
Statin & & \\
Other medications & 5 & $(1.4)$ \\
Antiarrhythmic drugs & 23 & $(6.6)$ \\
Angiotensin receptor blocker & 45 & $(13.0)$ \\
Calcium channel blocker & 19 & $(5.5)$ \\
Digoxin & 96 & $(27.7)$ \\
Diuretic & 51 & $(14.7)$ \\
Long-acting nitrate & 14 & $(4.0)$ \\
Warfarin & & \\
\hline SD & &
\end{tabular}

$\mathrm{SD}=$ standard deviation.

*Unless indicated otherwise. ments in morbidity and mortality after acute myocardial infarction have been linked to the use of these classes of medications. ${ }^{1,2}$ The results indicate awareness on the part of the health care team of the importance of adhering to current standards of therapy. Another retrospective Canadian study published in 2005 reported rates of discharge prescribing for "ideal" patients after acute myocardial infarction of $85 \%$ for ASA, $78 \%$ for B-blockers, $72 \%$ for ACE inhibitors, and $61 \%$ for statins, all lower than the rates reported here. ${ }^{8}$ The demographic characteristics of our sample were similar to those in the earlier study.

In the current study, $28.9 \%$ of patients had a history of acute myocardial infarction at the time of admission. For this subgroup of patients, the percentages receiving ASA, B-blockers, ACE inhibitors, and statins at the time of admission were lower than the stated benchmarks. However, we did not determine the timeframe of the prior myocardial infarction, and it is possible that for at least some of these patients, the CCORT/CCS quality indicators for acute myocardial infarction, published in 2003, were not available at the time of the prior infarction. As well, this study examined only one type of inpatient process of care, i.e., the prescribing rate at discharge for 4 classes of medications. In particular, we did not measure rates of adherence to therapy after discharge. Rates of adherence to medications after discharge following acute myocardial infarction have been shown to decrease, especially within the first 2 years. ${ }^{9}$ This may explain, at least in part, why the subset of patients with a history of acute myocardial infarction had lower use of these classes of medications on admission.

During the study period, there was no formal process (e.g., preprinted forms) for prescribing of medications at discharge after acute myocardial infarction, yet the prescribing rates for the medications of interest were above the benchmarks. This may have been due to the conduct of the study at 2 teaching centres for medical and allied health students, and the organization's promotion of a team approach to patient care. This appears to have created an environment in which multiple opportunities existed for health care providers to avail themselves of information about guideline-recommended therapies. In addition, given the relatively small group of specialist physicians, nurses, residents, and pharmacists caring

Table 3. Medication Use at Discharge among the 346 Patients

\begin{tabular}{lcccc} 
Medication & $\begin{array}{c}\text { No. of } \\
\text { Patients } \\
\text { Ineligible* }\end{array}$ & $\begin{array}{c}\text { No. of "Ideal" } \\
\text { Patients } \\
\text { (Total - Ineligible) }\end{array}$ & $\begin{array}{c}\text { No. (\%) of Ideal Patients } \\
\text { with Prescription for } \\
\text { Medication at Discharge }\end{array}$ & $\begin{array}{c}\text { Benchmark }^{6} \\
\text { (T) }\end{array}$ \\
\hline ASA & 35 & 311 & $308(99.0)$ & $\geq 90 \%$ \\
B-Blocker & 24 & 322 & $310(96.3)$ & $\geq 85 \%$ \\
ACE inhibitor & 54 & 292 & $264(90.4)$ & $\geq 70 \%$ \\
Statin & 33 & 313 & $278(88.8)$ &
\end{tabular}

$\overline{\mathrm{ACE}}=$ angiotensin-converting enzyme, ASA = acetylsalicylic acid.

*Patients with contraindications or other documented reason. 
for these patients, care providers were able to meet and discuss treatment options through activities such as continuing education, journal clubs, and patient care rounds. The retrospective nature of the study allowed a snapshot of "real world" practice in the care of patients with acute myocardial infarction at the authors' institution.

\section{Limitations}

The CCORT/CCS document listed exclusion criteria for each class of medication, and we relied on documentation in the medical records to determine whether patients met these exclusion criteria; however, we could not always identify a reason why a medication had not been prescribed for a particular patient. Documentation in hospital medical records has been shown in previous studies to be less than optimal..$^{10}$ In theory, there might have been more patients in the current study who had undocumented contraindications to the medications of interest than we were able to identify. This would have led to overestimation of the number of "ideal" patients and underestimation of prescribing rates.

This study was carried out several years ago, and the data may therefore not be entirely applicable or relevant today. However, the practice model of care for patients with acute myocardial infarction has remained consistent at these 2 acute care sites, and we therefore believe that these results reflect the appropriateness of this aspect of care.

\section{CONCLUSIONS}

At the authors' institution, rates of prescribing of ASA, ß-blockers, ACE inhibitors, and statins for "ideal" patients discharged after acute myocardial infarction exceeded published Canadian benchmarks. These results indicate that it is possible to meet the CCORT/CCS benchmarks for this aspect of post-infarction care, even without a formal initiative focused on discharge prescribing. Nonetheless, periodic monitoring will be required to ensure that Eastern Health continues to meet these standards.

\section{References}

1. Anderson JL, Adams CD, Antman EM, Bridges CR, Califf RM, Casey DE Jr, et al. ACC/AHA 2007 guidelines for the management of patients with unstable angina/non-ST-elevation myocardial infarction: a report of the American College of Cardiology/American Heart Association Task Force on Practice Guidelines (Writing Committee to Revise the 2002 Guidelines for the Management of Patients with Unstable Angina/Non-ST-Elevation Myocardial Infarction). J Am Coll Cardiol 2007;50(7):e1-e157.

2. Canadian Cardiovascular Society; American Academy of Family Physicians; American College of Cardiology; American Heart Association; Antman EM, Hand M, Armstrong PW, Bates ER, Green LA, Halasyamani
LK, et al. 2007 focused update of the ACC/AHA 2004 guidelines for the management of patients with ST-elevation myocardial infarction: a report of the American College of Cardiology/American Heart Association Task Force on Practice Guidelines. J Am Coll Cardiol 2008;51(2):210-247.

3. Rogers WJ, Canto JG, Lambrew CT, Tiefenbrunn AJ, Kinkaid B, Shoultz DA, et al. Temporal trends in the treatment of over 1.5 million patients with myocardial infarction in the US from 1990 through 1999: the National Registry of Myocardial Infarction 1, 2 and 3. J Am Coll Cardiol 2000;36(7):2056-2063.

4. Gregor RD, Bata IR, Brownell B, Wolf HK. Trends in the in-hospital treatment of acute myocardial infarction between 1984 and 1993-the Halifax County MONICA Project. Can J Cardiol 2000;16(5):596-603.

5. Tu JV, Austin P, Rochon P, Zhang H. Secondary prevention after acute myocardial infarction, congestive heart failure and coronary artery bypass graft surgery in Ontario. In: Naylor CD, Slaughter PM, eds. Cardiovascular health and services in Ontario: an ICES atlas. Toronto (ON): Institute for Clinical Evaluative Sciences; 1999. p. 199-238.

6. Tran CT, Lee DS, Flintoft VF, Higginson L, Grant FC, Tu JV, et al. CCORT/CCS quality indicators for acute myocardial infarction care. Can J Cardiol 2003;19(1):38-45.

7. Interventions: Acute myocardial infarction. In: Safer Healthcare Now! [website]. Edmonton (AB): Canadian Patient Safety Institute; [cited 2008 May 9]. Available from: www.saferhealthcarenow.ca/EN/Interventions/ ami/Pages/default.aspx

8. Canadian Cardiovascular Outcomes Research Team. Quality of cardiac care in Ontario. Phase I, Report 2: EFFECT (enhanced feedback for effective cardiac treatment). Toronto (ON): Institute for Clinical Evaluative Sciences; 2005. Available from: www.ices.on.ca/file/CCORT_EFFECT_ Phase1_Report2_final.pdf

9. Blackburn DF, Dobson RT, Blackburn JL, Wilson TW, Stang MR, Semchuk WM. Adherence to statins, beta-blockers and angiotensin-converting enzyme inhibitors following a first cardiovascular event: a retrospective cohort study. Can J Cardiol 2005:21(6):485-488.

10. Cox JL, Zitner D, Courtney KD, MacDonald DL, Paterson G, Cochrane $B$, et al. Undocumented patient information: an impediment to quality of care. Am J Med 2003;114(3):211-216.

Stephanie W Young, BSc(Pharm), ACPR, PharmD, MSc(Med), is with the School of Pharmacy, Memorial University, St John's, Newfoundland and Labrador.

John J Hawboldt, BSP, ACPR, PharmD, is with the School of Pharmacy, Memorial University of Newfoundland Health Sciences Center, St John's, Newfoundland and Labrador.

Neil J Pearce, MD, FRCP(C), is with the Division of Cardiology, Eastern Health, St John's, Newfoundland and Labrador.

\section{Address correspondence to:}

Dr Stephanie W Young

School of Pharmacy

Memorial University

300 Prince Phillip Drive

St John's NL A1B 3V6

e-mail: swyoung@mun.ca

\section{Acknowledgements}

The authors would like to acknowledge Gloria Kent, RN, for her assistance with data collection, data entry, and analysis and the Cardiac Program of Eastern Health for the provision of additional nursing staff to complete the data collection. 